\title{
ARTICLE NARRATIVE IDENTITIES AND THE PLEBISCITE IN PARÁ:

\author{
an analysis of the front pages for \\ O Liberal and Diário do Pará
}

Copyright @ 2017 SBPjor / Associação Brasileira de Pesquisadores em Jornalismo

\author{
ALDA CRISTINA COSTA \\ Federal University of Pará, Brazil \\ THAÍS LUCIANA CORRÊA BRAGA \\ Federal University of Pará, Brazil \\ EVELYN CRISTINA FERREIRA DE AQUINO \\ Federal University of Pará, Brazil
}

\begin{abstract}
On December 11, 2011, a plebiscite was held in Pará proposing to create two separatist states, Carajás and Tapajós, out of the state of Pará. The public voted against both projects. This article analyzes the narrative identities found on the front pages of $O$ Liberal and Diário do Pará newspapers about the plebiscite in Pará. Depth Hermeneutics (DH), as proposed by Thompson (2011), was used as the methodological reference. $\mathrm{DH}$ emphasizes the object of analysis as a meaningful symbolic construction requiring interpretation. Narrative analysis, as proposed by Motta (2007), was the main research technique used to highlight the movement of construction of journalistic (discursive) characters. The narrative identities built by the two newspapers showed that both were against the creation of the new states, but for very different reasons. The flag of Pará was the main object used to induce the idea of unity.
\end{abstract}

Key words: Narrative identities. Depth Hermeneutics. Plebiscite in Pará. Amazon.

\section{IDENTIDADES NARRATIVAS E O PLEBISCITO NO PARÁ: análise das primeiras páginas de $O$ Liberal e Diário do Pará}

RESUMO - Em 11 de dezembro de 2011, o plebiscito no Pará propôs a criação dos estados de Carajás e de Tapajós a partir da divisão do estado do Pará. O resultado da consulta pública foi negativo aos dois projetos. $\mathrm{O}$ artigo analisa as identidades narrativas constituídas pelas primeiras páginas dos jornais O Liberal e Diário do Pará sobre o plebiscito no Pará. Utilizou-se como referencial metodológico a Hermenêutica em Profundidade (HP), proposta por Thompson (201 1). A HP evidencia o fato de que o objeto de análise é uma construção simbólica significativa, que exige uma interpretação. Como principal técnica de pesquisa, a análise narrativa, proposta por Motta (2007), com ênfase no movimento de construção de personagens jornalísticas (discursivas). As identidades narrativas construídas pelos dois jornais indicaram que ambos eram contrários à criação dos novos estados, porém, por motivos divergentes. A bandeira do Pará foi o principal elemento utilizado para evocar a ideia de unidade.

Palavras-chave: Identidades Narrativas. Hermenêutica de Profundidade. Plebiscito no Pará. Amazônia. 


\title{
IDENTIDADES NARRATIVAS Y PLEBISCITO EN PARÁ: análisis de las primeras páginas de $O$ Liberal y Diário do Pará
}

\begin{abstract}
RESUMEN - En 11 de diciembre de 2011, el plebiscito en Pará propuso la creación de los estados Carajás y Tapajós a partir de la división del estado Pará. El resultado de la consulta pública fue negativo para los dos proyectos. El artículo analiza las identidades narrativas constituidas por las primeras páginas de los periódicos O Liberal y Diario de Pará acerca del plebiscito en Pará. Fue utilizado como referencia metodológica la Hermenéutica en Profundidad (HP), propuesto por Thompson (2011). La HP pone de relieve el hecho de que el objeto de análisis es una construcción simbólica significativa, lo que requiere una interpretación. Como principal técnica de la investigación, el análisis narrativo, propuesto por Motta (2007), con énfasis en el movimiento de construcción de personajes periodísticos (discursivos). Las identidades narrativas construidas por los dos periódicos han indicado que ambos se opusieron a la creación de los nuevos estados, pero por diferentes razones. La bandera de Pará fue el elemento principal que se utilizó para evocar la idea de la unidad. Palabras clave: Identidades narrativas. Hermenéutica in Profundidad. Plebiscito en Pará. Amazonas.
\end{abstract}

\section{Initial considerations}

A plebiscite is a public vote on an issue that public authorities consider important for social life (AQUINO, 2013, p.7). The plebiscite in Pará, held on December 11, 2011, brought 4,848,495 Pará voters to the polls to decide on whether to create two separate states, Carajás and Tapajós, out of the existing Pará state. The questions were based on legislative acts 136 and $137 / 2011$, issued on May 26th and June 2 nd, 2011 , respectively.

Up until 1988, the formation or dissolution of new Brazilian states had been the prerogative of the Union. It became an issue of public vote once the Magna Carta had been established which, in article 18, calls for a plebiscite to be held on issues of partition, either the inclusion or breaking up of states, or on creating new federal territories (BRAZIL, 1988).

Most of the Pará voters responded negatively to the two issues - around $66 \%$ voted against it, according to the Superior Electoral Court (HEC). Legally, Pará still represents the Northern region; the second largest Brazilian State in the country with an area of $1,247,954,320 \mathrm{~km}^{2}$ and a population of $8,073,924$ distributed among 144 municipalities, according to the Brazilian Institute of Geography and Statistics. Economically and socially speaking, 
however, Pará is "fractured, with autonomous poles, independent even from [...] the leaders who are trying to facilitate a new spatial design for the Amazon" (PINTO, 1994, p. 8).

The following question is put forth: what are the narrative identities on the plebiscite in Pará which are printed on the front pages of the December 11 th, 2011 editions of O Liberal and Diário do Pará newspapers? These newspapers are the largest and more significant ones in the state of Pará, according to the media system in the Northern region of the country. It is called a narrative because "it is within the narrated story, its characters of unity, its internal and complete articulation given by the plot's writing that the character maintains an identity correlative to his/her own history throughout the story" (RICOEUR, 2014, p.149). No other news items from the front pages were considered, only the headlines pertaining to the plebiscite in Pará.

Depth Hermeneutics (DH), as proposed by Thompson (2011), is the chosen methodology. Known as an interpretation methodology, $\mathrm{DH}$ highlights the fact that the object of analysis is a meaningful symbolic construction which needs to be interpreted. Ricoeur (1978, p. 15) defines symbolic as the characteristic of any structure of meaning in which a direct, primary, literal meaning denotes another indirect, secondary, figurative one that can only be understood through the former. Therefore, the interpretation means deciphering the hidden meaning in the apparent sense, in other words, revealing the levels of meaning implied in literal meaning.

The plebiscite in Pará was seen as a symbolic construction since the information about the public vote was based on ideologies held by $O$ Liberal and Diário do Pará newspapers. Van Dijk (1998, p. 8) explains that ideologies "allow people, as members of a group, to organize a multitude of social beliefs about what is good or bad, right or wrong, and then act accordingly".

The interpretive structure proposed in $\mathrm{DH}$ is made up of three main procedures: socio-historical analysis, formal or discursive analysis and interpretation/re-interpretation. In this article, the socio-historical analysis comprises the historical-geographical characterization of Pará state, placing emphasis on the formation of the territories of Carajás and Tapajós. The political-communication background of the newspapers O Liberal and Diário do Pará was also considered at this initial moment.

The formal or discursive analysis was based on a pragmatic analysis of the journalistic narrative which establishes sequences of 
continuity (or discontinuity), and integrates actions from the past, present and future. For Motta (2007, p. 146), narratives are forms of relationships established by culture; the coexistence between living beings who share interests, desires and wills, and live under the constraints and social conditions of hierarchy and power.

The author proposes six steps for a pragmatic analysis of journalistic narratives: 1) rewriting the story or the journalistic event; 2 ) identifying the conflicts and the functionality of the episodes; 3 ) constructing journalistic (discursive) characters; 4) communicative strategies which are divided into subsections a) objective strategies (constructing the effects of reality) and b) subjective strategies (construction of poetic effects); 5) the communicative relationship and the "cognitive contract"; 6) metanarratives (meanings based on morals or storytales).

In this article, only one of the author's six movements was used: the construction of journalistic (discursive) characters. In order to perform a better formal or discursive analysis for the second phase of $\mathrm{DH}$ an intermediate section was opened that discusses narratives, identity and ideologies on a theoretical level (FRANÇA, 2002; GEERTZ, 2015; LEAL, 2006; MOTTA, 2007; MARTINO, 2010, 2016; RICOEUR, 2006, 2010, 2014; THOMPSON, 2011; VAN DIJK, 1998, 2015). Van Dijk's (2000) model for analyzing news was applied for pragmatic analysis of the journalistic narrative.

The third $\mathrm{DH}$ procedure of interpretation/reinterpretation constitutes a new movement of thought, a synthesis which brings about the meaningful construction of new meanings (THOMPSON, 2011 , p. 375). This phase, facilitated by the previous ones, is explained in the final considerations of this article. It deals with important thoughts on journalistic activity in Pará and in the Brazilian Amazon.

\section{The plebiscite in Pará as a symbolic construction}

Pará state is a part of the Brazilian Amazon - a region that was consolidated by its autonomy and remoteness from the rest of Brazil and Latin America. Paes Loureiro (1995, p. 25) points out that challenges to accessing the Amazon rainforest, the development of a mainly export economy run on indigenous labor (not slave plantations) as well as having a large indigenous population are all factors that have contributed to the uniqueness of Amazonian culture. 
The attempt to connect the Amazon to other Brazilian regions gained momentum with the government of then president Getúlio Vargas (1930-1945), which was looking to establish an active domestic market. Each Brazilian region should contribute its unique production, an idea of "regional vocation". The exporting possibilities that the Amazon provides led the government to encourage occupation of the Amazonian border (BUENO, 2002, p. 69).

One of the strategies the federal government used to occupy, delimit and, as a consequence, control the Amazon was to integrate it through state highways such as the Trans-Amazonian Highway and the Perimetral Norte (North Perimeter), and regional highways from Cuiabá-Santarém and Porto Velho-Manaus (BECKER, 1997, p. 14). However, according to Paes Loureiro (1995, p. 25), it was the opening of the Belém-Brasilia road in 1961 that made the Amazon slightly more accessible. Highways became the route of choice for transport (both people and goods and services), leaving waterways virtually unused. The center of the valley had moved to dry land.

Another strategy this government adopted was to subsidize capital and increase migration - mainly from the southeastern region and abroad (BECKER, 1997, p. 19). Since the 1980s, largescale mineral resources have been exploited by state-owned and/or foreign companies, including searching for gold in the mines. One of the most important mining discoveries was the metal-rich province of the Eastern Amazon, located between the Araguaia and Xingu rivers in the south of Pará. Large-scale projects were developed ${ }^{2}$ in order to control the territory and organize production.

The expansion of the Amazon border resulted in violent conflicts between companies, gold miners and indigenous peoples, not only over the land but also over the territories where the deposits are located. The conflict between the government's highway network and the socio-political network of the social groups who have settled in the Amazon forced proposals to be rewritten and a break-up of official administrative regions.

The homogenizing integration imposed by the federal government's network is by no means absolute or total. The Amazon has never been homogeneous and today it is going through a rapid destruction/construction process, it is becoming fragmented into sub-regions built by new societies. This differentiation is the result of State action and the initiative and conflict from the different social groups, in other words, social practice (BECKER, 1997, p, 96). 
Southern Pará, which includes the territory of Carajás, was formed by rubber tappers who had been extracting latex from the area since the mid-nineteenth century. Schmink and Wood (2012, p. 195) explain that by the end of the nineteenth century the rubber tappers had founded settlements on the banks of Tocantins and along the Araguaia and Xingu rivers. The highly unfair trading mechanism called aviamento (where indigenous people buy the goods needed to support their livelihood on credit and at inflated prices) led to land supply routes being established, connecting river basins which are hundreds of kilometers apart.

Marabá, the unofficial capital of Carajás state, was founded by merchants who got rich off the rubber trade. When the rubber trade came to an end, Brazil nuts became the main export from southern Pará. Traders from Marabá began to pressure the state government for local political autonomy. The idea was for Marabá to fall under the jurisdiction of Goiás state or to create a new state. Traders celebrated a victory in 1913 when Pará state separated Marabá from the municipality of São João do Araguaia and appointed a government board to control the newly created municipality (SCHMINK; WOOD, 2012, p. 196).

In Tapajós, the first attempt at territorial division dates back to 1849 with a study done by the Viscount of Porto Seguro, Francisco Adolfo de Varnhagen, in it he proposed the territorial and political rearrangement of Brazil. Although the name Tapajós was not mentioned, Pará was the object of three subdivisions. With the creation of Amazonas in 1850, disputes still remained over the boundaries between the states of Amazonas and Pará. In order to avoid any potential conflicts, the idea of creating a third province arose, "situated more or less between those two, encompassing the regions of Óbidos, Parintins and Santarém, the latter being the capital city" (DUTRA, 1999, p. 18).

Several proposals for autonomy have surfaced since then for the area known as the "West of Pará". The concept dates back to 1985 when the Committee for the Creation of Tapajós State was created.

The name crystallized itself in Tapajós and the region began to be conceptualized politically like the West of Pará due to the traditional Lower Amazonas not being included within the new centers or undergoing changes brought on by the opening of the Trans-Amazonian and SantarémCuiabá highways. The West began to present new socioeconomic and cultural realities, the riverside towns differed from the centers which were affected by the road 
transport policy partially implemented in the region by the federal government and by the immigration which brought on changes to the political field (DUTRA, 1999, p. 22).

According to Castro (2011, p. 2), one of the issues facing the homogenization of the West of Pará is that the concept covers at least three different territories: 1) the Lower Amazonas, with two distinct and competing internal territories - Santarém and Calha Norte; 2) the Xingu, centered in Altamira and also with its different internal spaces - the Altamira pole, which connects to the Trans-Amazonian Highway, and the immense sparsely-populated space south of the Xingu; 3) High Tapajós, centered in Itaituba.

\section{Political and communication adversity betwwn O Liberal and Diário do Pará}

There are five Amazonian communication groups that extend themselves regionally or even nationally. Two in Pará state: Romulo Maiorana Organizations (RMO) and Amazon Brazil Network (ABN), both responsible for $O$ Liberal and Diário do Pará newspapers. Two in Amazonas state: the Amazonian Network and the Calderaro Communication Network, also known as The Critic; and one in Tocantins state - the Jaime Câmara Organizations (CASTRO, 2012). Pinto $(2015$, p. 171) claims that in total there are ten media groups (commercial, religious and public) operating in Pará state.

Founded on November 15, 1946, O Liberal, run by Joaquim Cardoso de Magalhães Barata ${ }^{3}$, was looking to officially represent the Social Democratic Party (SDP). His first order of business was patenting the political identity of the newspaper. Then, $O$ Liberal provided opposition to the Folha do Norte - owned by the family of political rival, Paulo Maranhão. In 1966, O Liberal took on a more corporate identity under the ownership of Romulo Maiorana; it became an early morning newspaper and had changes made to the graphic design and presentation of its news articles - avoiding any political wars. Romulo Maiorana died in 1986 and the presidency of the newspaper was passed on to firstborn son, Romulo Maiorana Júnior - who today also presides over the RMO, a journalistic corporation belonging to the Maiorana family, a family which owns $A M$ and FM radio stations and open television (affiliated to Globo Network), as well as a cable TV operator and news portal 
(MASSARANI; SEIXAS; CARVALHO, 2013, p. 83; SEIXAS; CASTRO, 2014, p. 103; VELOSO, 2008, p. 76).

The Diário do Pará was created on August 22, 1982 in order to fight $O$ Liberal's support the election of businessman Oziel Carneiro to state government, as well as to subsidize the opposition candidate - Jader Barbalho (Brazilian Democratic Movement Party - PBDM) -, who won the election. The main financial backer for Diário do Pará, including its graphic system, was former governor of the state of São Paulo, Orestes Quércia, who at the time, was thinking of running for presidency of the Republic (PINTO, 2007).

As soon as Jader Barbalho was elected governor, O Liberal offered to support him. But, the Maiorana family's real goal was to dissuade the politician from investing in his new career. The advertising for Jader Barbalho's (1982 to 1986) first mandate was funded by $O$ Liberal. However, instead of discarding Diário do Pará, Jader Barbalho decided to make it competitive, replacing the old press machines with offset ones. Jader's campaign newspaper "was still, technologically, a step behind O Liberal, but not as far behind as before" (PINTO, 2007).

The Maiorana family's response to the political ascent ${ }^{4}$ of Jader Barbalho was revealed by their increasing connections to the former governor's political opponents. O Liberal gave Jader's opponents a space in which to attack him publicly. At the same time, the RMO newspaper received investments for official advertising. The Maiorana family's longest-lasting alliance was made in 1994 with a political group from Pará when Almir Gabriel (Party of Brazilian Social Democracy - PBSD) was elected to state government. 12 years of intense PBSD propaganda in the newspapers and on RMO radio and TV stations had passed by the time that Almir Gabriel had been reelected in 1998 and his successor, Simão Jatene, elected in 2002 (VELOSO, 2008, p. 84).

The competition between the two groups - RMO and ABN - ended up structuring political life in the state. Their polarizing relationship and their political activity in the state of Pará have intensified since 2002 with O Liberal beginning to lose business to the competitor Diário do Pará. "With an aggressive policy of investment and marketing, Jader Barbalho's newspaper gained space and, consequently, political expression in the local market, building a polarizing competition that, although does not generate quality content, has the ability to create its own agendas" (CASTRO, 2012, p.182). 
The importance of $O$ Liberal and Diário do Pará for RMO and $A B N$ should not be neglected since newspapers are "run as real economic bastions of their political influence and are used to blackmail companies and the public in many ways in order for them to capitalize" (CASTRO, 2013). Similarly, because they are printed media, RMO and ABN have more space than the restricted period of journalism allows. This is possible by having an affiliation agreement with a national television network. According to Castro (2013), printed journalism in Pará is the model of propaganda because it revolves around the interests of communication groups.

$O$ Liberal has consolidated itself as a newspaper that mostly supports the PBSD governments. Diário do Pará is a campaign newspaper designed to defend the interests of Jader Barbalho, the PBDM and some allies in the local political scene (VELOSO, 2008, p. 86). Currently, $O$ Liberal calls itself "the biggest, the best" in the North and Northeast. However, it has refused to be audited on circulation. It has not been affiliated to the Institute for Verifying Circulation (CVI) since 2006 when they presented fraudulent numbers to the organ (PINTO, 2013).

Diário do Pará, on the other hand, does not disclose information about the circulation it receives from the CVI. The ABN newspaper prefers data from the Brazilian Institute of Public Opinion and Statistics (Ibope) because, according to Pinto (2013), Ibope counts its audience by measuring how many people read a single newspaper. The CVI does not check newspaper sales and both O Liberal and Diário do Pará do not make this information available to the public.

\section{Narratives, identities and ideologies: theoretical perspectives}

For Martino (2016, p. 42), the narrative act represents a privileged moment in which to consider and understand the act of communication as a way of meeting another person since narrating presupposes some type of relation, however minimal that may be, with the person whom it is narrated for. Therefore, the narrative act is designed overall as a deliberate act of symbolic sharing between two or more people who have a certain capability for understanding, or at least perceiving, the implications of these elements.

Once legitimate, narrative knowledge enables a subject, the world and experience to all integrate together. Leal (2006, p. 20) sees narrating as finding and establishing sequence and direction. It means giving roles to the subject and creating characters, and indicating a 
solution. According to the author, narratives weave the experience of life and can appear in the stories of daily life that humans tell, helping them live and group together, distinguishing them from others, marking their places and making communities possible. To do this, it is necessary to design a "narrative look" capable of establishing articulations between the various fragments in circulation.

Ricoeur (2010, p. 98) believes that every narrative presupposes that the narrator and his audience are familiar with terms such as agent, objective, means, circumstance, help, hostility, cooperation, conflict, success, failure, etc. For this French philosopher, narratives are about acting and suffering. Similarly, the narrative adds discursive aspects that distinguish it from a simple sequence of action phrases. They are "forms of syntax, the function of which is to compose speech modalities worthy of being called narratives" (RICOEUR, 2010, p. 99).

The author explains that narrating involves telling who does what, why and how, and connecting these aspects over a span of time. The character is composed within a plot, meaning the character in the narrative is not an entity distinct from his experiences, but rather someone who shares their personal dynamic identity with the story being told. "The narrative builds on the character's identity, which we can call his narrative identity, adding to the identity of the narrated story. It is the identity of the story that shapes the character's identity" (RICOEUR, 2014, p.155).

Here, identity is not associated with nationality or with the search for origins but rather to the dialectic between individuality and sameness. Ricoeur (2014, p. 115) explains that personal identity, as sameness or idem, has a numerical and qualitative character. It means uniqueness, contrary to plurality, and is a re-identification of the self, also having to do with extreme similarity. So, personal identity must have uninterrupted continuity between the first and last stage of the individual's development as well as presenting a principle of permanent time.

This is the reason the author proposes for studying the ipseity of the self, which implies some form of permanence in time that is not reduced to a substrate. The intervention of narrative identity is therefore conceived as personal identity acting as a specific medium between the center of the character - the set of distinctive marks that make it possible to re-identify an individual, where idem and ipse tend to coincide - and the center of self-preservation, where ipseity is quite separate from sameness.

Narrative identity does not eliminate personal identity but 
places it in a dialectical relation with ipse identity. Memory (facing the past) and promise (facing the future) are placed differently between sameness and ipseity in the dialectic. With memory, the emphasis is put on sameness; in promise, it is put on ipseity. Both are related to the threat of a constitutive negative meaning: forgetfulness for memory and betrayal for promise (RICOEUR, 2006, p. 124).

The otherness (or relation with the other) comes from the promise. Symbolic mediations are representations that contribute to establishing a social bond, it symbolizes identities. This means that establishing social bond occurs by agreement, that is, the content of the search for identity.

On the one hand, the sphere of representations holds the role of symbolic mediator and thus brings to the fore the question of the identity of the social entities at play. On the other hand, the field of social practices puts in the place of honor the agent of change, the social protagonist, both on a collective and individual level (RICOEUR, 2006, p. 150).

The philosopher explains that all establishments are potentially of a reconstructive nature provided they do not continually repeat and that they prove to be innovative to some degree. It is important to bring Ricoeur's (2006, 2010, 2014) considerations closer to Martino's studies (2010, p.14), who believes identity is something that is produced and transformed into a message, re-shaped by subjects in communication.

According to this Brazilian author, identity is related to the way the world is explained, to the criteria that each person uses to define situations and people; that is, to the narratives that are constructed about reality. Identity relates dialectically with everyday life in the paradoxical sense of keeping it in full transformation. In identity narratives, the other has a specific place - it is imagined as much as the "self". For this reason, the question of identity is both reflexive and self-reflexive. "People define themselves in relation to themselves, but also in relation to others, to the groups with whom they live, to the political, social and economic situations in which they live" (MARTINO, 2010, p. 34).

Martino's concept is not too dissimilar to that of França (2002, 27 ), who believes the discussion of identity represents the discussion of otherness, of difference. He sees identity as a process; as a production that is never completed, being formed and transformed within the representation. 
Identity has to do with discourses, objects, symbolic practices that position us in the world - that say our place in relation to another (other points of reference, another place). In doing so, identity also marks and establishes a position, the place we actually construct and in which we enter. It is constructed so - at this intersection between the discourses that position us and our movement to position ourselves as subjects in the world (FRANÇA, 2002, p. 28).

The Brazilian researcher draws attention to the dynamics, to the game of positioning founded on the existence of one and the other, brought together by the relationship that constitutes them. Identity, highlighted as a mobile process by Martino (2010) and França (2002), is similar to the dialectic between sameness and ipseity typically found in the narrative identity proposed by Ricoeur (2006, 2010, and 2014). According to the philosopher, it is in confrontation with another (individual or collective) that the narrative identity reveals its fragility, so much so that the ideologies of power seek to manipulate these fragile identities through the bias of symbolic mediation of action. This becomes possible because of the varied resources that narrative configuration offers.

Leal's perspective (2006, p. 26) is that narratives present themselves as a space of tension, in which coercion, resistance, consonances and dissonances coexist. Motta (2007, p. 143), who believes narrative statements put things in order and perspective in a logical and chronological process, therefore furthering this point of view: the media narrative discourses are constructed by communicative strategies and they require linguistic and extra linguistic operations and options in order to realize certain intentions and goals.

The narrative organization of media discourse is not random; it occurs in pragmatic and political contexts, as well as produces certain effects (consciously or unconsciously). When a narrator shapes a discourse into its narrative form, it introduces an illocutive force responsible for the effects that it will generate in the recipient (MOTTA, 2007, p. 144).

The author understands that media narratives are not only representations of reality, but also forms of organizing actions around a context of cultural strategies. Narratives and narrations become discursive devices used socially according to the wishes of the narrator. Narratives and narrations become exercises of power and hegemony in different places and situations of communication. Narratives and narrations realize sociocultural acts and performances, and not just represented in reports (MOTTA, 2007, p. 145). 
Ideologies come in here as a cultural system that responds to tension and becomes a vital source for sociopolitical meanings and attitudes (GEERTZ, 2015, p. 125). In an apologetic and justifying way, ideology refers to the part of culture actively concerned with establishing and defending belief patterns and values. The anthropologist's perspective resembles Van Dijk's (2015, p. 48) perspective; he believes ideologies are complex cognitive structures that provide coherence to social attitudes - which, in turn, determine social practices. In journalistic media, the strategy of knowledge control is exercised through the selective restriction of subjects and, more generally, through specific reconstructions of social and political realities. The process is driven by a system of values and professional ideologies about the news and what it should or should not be.

Thus, Geertz's (2015) and Van Dijk's (1998; 2015) understanding of ideologies conforms to Thompson (2011, p. 76), who states: ideological phenomena are significant symbolic phenomena as long as they serve, in socio-historical circumstances, to establish and to sustain relations of domination. Hence, the importance of examining the interaction of meaning and power in particular circumstances.

\section{Pragmatic analysis of the journalistic narrative: discursive characteres}

This article deals with building journalistic (discursive) characters, in line with Motta (2007, p. 152), to identify the narrative identities found on the front pages of $O$ Liberal and Diário do Pará about the plebiscite in Pará, both published on December 11, 2011. The journalistic character is not a purely fictional and arbitrary entity created as the author sees fit (which is what happens in art) but is rather a product of a factual narrative. Motta (2007, p. 153) explains that the character is presented to the public by the narrator, the mass media - and the narrator leaves impressions in the readers' minds upon which he builds the character.

In order to look at the structure of news for the two newspapers in this study, we applied concepts to the following formal categories: schematic superstructures, which describe the 
overall form of a discourse; and thematic macrostructures, the general organization of global "topics" (VAN DIJK, 2000, p. 123). Tables 1 and 2 show the schematic superstructures and thematic macrostructures observed on the front pages of $O$ Liberal and Diário do Pará on December 11, 2011. Figures 1 and 2 are news advertisements about the plebiscite in Pará, published in the RMO and $A B N$ newspapers.

Table 1 - News structure on the plebiscite in Pará from $O$ Liberal

\begin{tabular}{|c|c|c|}
\hline \multicolumn{3}{|c|}{ O LIBERAL } \\
\hline CATEGORIES & $\begin{array}{c}\text { SCHEMATIC } \\
\text { SUPERSTRUCTURES }\end{array}$ & $\begin{array}{c}\text { THEMATIC } \\
\text { MACROSTRUCTURES }\end{array}$ \\
\hline Headline & $\begin{array}{l}\text { Today, } 4.8 \text { million decide } \\
\text { on the division of the } \\
\text { State }\end{array}$ & $\begin{array}{l}\text { Highlighted by the large } \\
\text { number of voters. }\end{array}$ \\
\hline Subheading 1 & $\begin{array}{l}14,281 \text { polling stations } \\
\text { will be open throughout } \\
\text { Pará from } 8 \text { am to } 5 \mathrm{pm} \text {. }\end{array}$ & $\begin{array}{l}\text { The effects of } \\
\text { constructing reality by } \\
\text { emphasizing the number } \\
\text { of sections and their } \\
\text { operating hours. }\end{array}$ \\
\hline Subheading 2 & $\begin{array}{l}\text { For the first time in its } \\
\text { history, the population } \\
\text { of Pará is going to the } \\
\text { polls to decide on the } \\
\text { division of their territory, } \\
\text { voting for the creation } \\
\text { of Carajás and Tapajós } \\
\text { states. According to the } \\
\text { REC, the election will } \\
\text { cost } 13.5 \text { million. }\end{array}$ & $\begin{array}{l}\text { Emphasis placed on the } \\
\text { unpublished plebiscite in } \\
\text { Pará and also on the costs } \\
\text { of public voting. }\end{array}$ \\
\hline Infographic & This one? Or this? & $\begin{array}{l}\text { Carajás and Tapajós } \\
\text { are both waiting to be } \\
\text { approved or rejected. } \\
\text { The issue of public and } \\
\text { individual consultation } \\
\text { for each territory is } \\
\text { neglected. Disdain for the } \\
\text { separatist option. }\end{array}$ \\
\hline
\end{tabular}

Source: Authors 
Figure 1 - Plebiscite in Pará on the front page of $O$ Liberal

\section{Hoje, 4,8milhões decidem sobreadivisãodoEstado}

Em todo o Pará, vão funcionar 14.281 seções eleitorais, das $8 \mathrm{~h}$ às $17 \mathrm{~h}$ Pela primeira vez na história, a populaçò paraense sai às urnas decidir sobre a divisấo do seu território, visando a criaçăo dos estados de Carajás e do Tapajús. Segundo o TRE, a eleiçào vai custar RS 13,5 millixes, Pocer, 1 a 8.

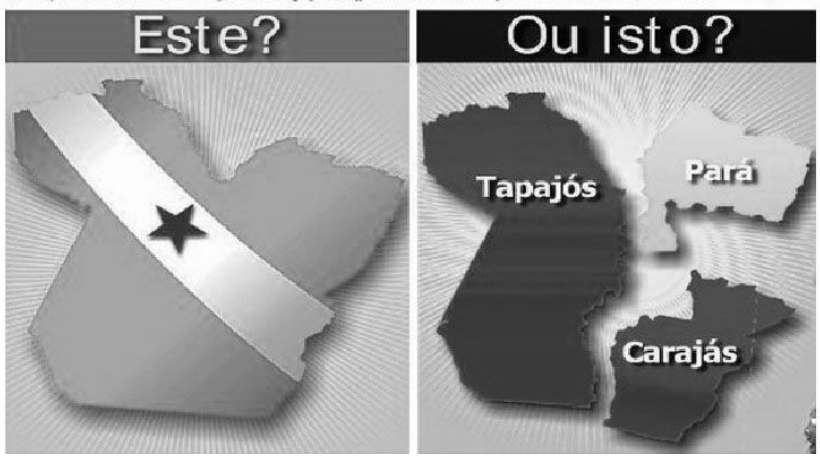

Source: Digital O Liberal

There were three formal categories explored in $O$ Liberal: headline, subheading and infographic (Table 1). The discursive constructions of the headline and the subheadings explore the effects of constructing reality by highlighting the total number of voters, the operating times and places of the polling stations, as well as the costs of public voting. This last discursive construction shows the marketing concern of $O$ Liberal in relation to the plebiscite.

As presented in section 2 of this article, the RMO newspaper is concerned about not opposing the government in order to obtain investment in advertising funds. $O$ Liberal has historically been close to the governments of the PBSD. It therefore defended its political alliance with Governor Simão Jatene in 201 1, who promised, a priori, to support the creation of new states as defined in the plebiscite. However, in that very same year he opposed the creation of new states, and encouraged forces and political agents to fight against the division of Pará.

In the $O$ Liberal infographic, the Pará flag, a symbol of the entire state, covered the map of the administrative unit itself (Figure 1). The headline "This one?" evoked feelings of unity and cohesion in the memory of the Pará voters. It erased the outrageous realities distinct to humans which are the result of highly impactful projects developed in the Amazon: Carajás-Parauapebas; hydroelectric of Tucuruí-city of Tucuruí; Monte Dourado-Beiradão; Vila dos Cabanos-Barcarena (PINTO, 
1994, p.9). Associating Pará with the flag is a strategy to re-identify the state at any time, in any place, assuming that its current configuration has always been and always will be the same.

The headline "Or this?" refers to the promise, to separating Pará into three states. The newspaper could have opted for the expression "Or these?" since the public vote was on two independent scenarios. However, O Liberal treats both territories, Carajás and Tapajós, as the only alternative. An alternative for which there is no known element to identify Carajás, Tapajós or the remaining Pará. The three states are presented without any connection and represent the negative version of what could have happened on December 11,2011.

Two formal categories were observed in the Diário do Pará: headline and subheading. However, the ABN newspaper used the Pará state flag as a background image to refer to the plebiscite (Figure 2). Separate groups of hands pull the flag as a sign of unity, but in a way, they give the opposite meaning since the flag is being pulled in opposite directions. Symbolically, the gesture of the hands represents struggle or competition. However, the struggle is not about rationality, it's about strength. There is no victory in arguments, only in brutality.

Table 2 - Structure of the news about the plebiscite in Pará in Diário do Pará

\begin{tabular}{|l|l|l|}
\hline \multicolumn{3}{|c|}{ DIÁRIO DO PARÁ } \\
\hline CATEGORIES & $\begin{array}{c}|c| \\
\text { SCHEMATIC } \\
\text { SUPERSTUCTURES }\end{array}$ & \multicolumn{1}{c|}{$\begin{array}{c}\text { THEMATIC } \\
\text { MACROSTRUCTURES }\end{array}$} \\
\hline Headline & Yes or no? & $\begin{array}{l}\text { Instead of questioning about } \\
\text { Carajás and Tapajós, it } \\
\text { focuses the political campaign } \\
\text { strategies used to support and } \\
\text { oppose the separation of Pará. }\end{array}$ \\
\hline Subheading 1 & $\begin{array}{l}\text { Pará people go to the } \\
\text { polls to decide the future } \\
\text { of the state }\end{array}$ & $\begin{array}{l}\text { Real Pará people are those who } \\
\text { advocate for the state to remain } \\
\text { united; the others are outsiders. }\end{array}$ \\
\hline $\begin{array}{l}\text { Shis is not a Sunday like } \\
\text { any other. It is a Sunday that } \\
\text { will make history for almost } \\
\text { million Pará voters, } \\
\text { called to the polls for an } \\
\text { unpublished state vote: } \\
\text { to decide if Pará remains } \\
\text { intact or if it will be divided } \\
\text { into two separate states - } \\
\text { Carajás and Tapajós. }\end{array}$ & $\begin{array}{l}\text { Highlight the unpublished } \\
\text { plebiscite in Pará. }\end{array}$ \\
\hline
\end{tabular}

Source: Authors 
Figure 2 - Plebiscite in Pará on the first page of Diário do Pará

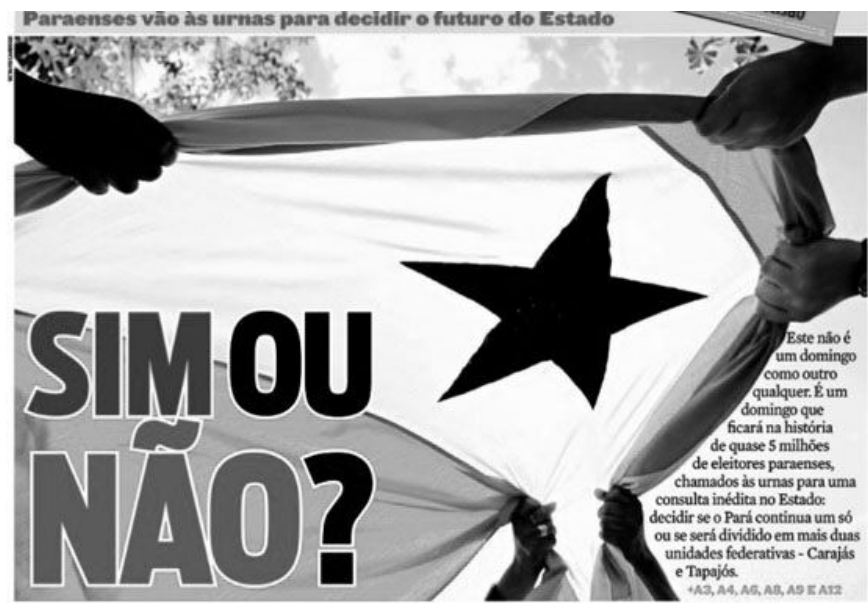

Source: Electronic version of Diário do Pará

The star in the center of the flag (Figure 2) alludes to the solitary star on the Brazilian flag - a symbol of the unity of state and nation - had its original color of blue changed to black. Color information is important because it incorporates values, rules and codes existing in systems or semantic fields of diverse origins, such as politics (GUIMARÃES, 2006, p. 3).

The front page of Diário do Pará, inferred a break in the historicalsymbolic meaning of the Pará flag. What was represented as a union in one context was represented in the plebiscite as a mourning, the "death" of Pará. There is clear dialectic between memory represented by the Pará flag and the promise - narrated as a negative future in which the state would separate. The idea of a negative future is reinforced by the fact that the conjunction "or" and the question mark are both printed in black.

Like O Liberal, Diário do Pará asked two questions: "yes" or "no" - a campaign strategy used by unified fronts (MENDONÇA; CAL, 2012, p. 112). "Yes" was written in green, the color used in material for pro-separatist states ${ }^{5}$. The same color predominates in the Marabá coat of arms and flag, the likely capital of the future Carajás state. "No", slightly larger than "Yes", was written in blue, which predominates in the original version of the Pará flag. The color blue, from the star to the word, inferred that the newspaper favored unity and was against the creation of the two new states of Carajás and Tapajós.

The Diário do Pará headline was about the decision of the Pará people. Geographically, all those who inhabit and/or were born in the state of Pará are Pará people. However, during the plebiscite in 
Pará, Mendonça and Cal (2012, p. 116) recall that the "real Pará people" were classified as the ones who fought against the separation of Pará. The inhabitants of the territories of Carajás and Tapajós, although they were clearly Pará people, were seen as outsiders, only interested in looting the riches of Pará. In evoking Pará people, Diário do Pará positions itself in favor of a united state territory.

The uniqueness of the public vote was highlighted in the discursive constructions for both newspapers. For the first time since the Magna Carta was established, O Liberal or Diário do Pará has been at the mercy of political groups holding a strong influence over the voting population. The need to build discursive strategies and use them according to their ideologies is therefore very important.

\section{Final considerations: interpretations/reinterpretations}

This article proposed to identify the narrative identities on the plebiscite in Pará found on the front pages of $O$ Liberal and Diário do Pará newspapers, both published on December 11, 2011. DH (THOMPSON, 2011) was the chosen methodology to answer such a problematic question associated to the technique of pragmatic analysis of journalistic narrative (MOTTA, 2007), with an emphasis on the movement of construction of journalistic (discursive) characters. Analysis of the news structure (VAN DIJK, 2000), also used as a research tool, allowed us to interpret/reinterpret the symbolic construction of the plebiscite in Pará in the Pará newspapers.

Castro $(2012,2013)$ shows that $O$ Liberal and Diário do Pará hold importance and prestige outside the state boundaries, pari passu to the largest communication groups in the Amazon. Their journalistic approaches are strategic and show their politicalideological positions. In general, O Liberal opts not to antagonize the situated governments while Diário do Pará supports the direct interests of Senator Jader Barbalho - one of the most influential politicians in Brazil who carries a lot of weight in political circles and is often involved in scandals of corruption.

Pinto $(2007,2013)$ is one of the few to question the origin of the two Pará newspapers and the fact that both have become powerful in the Amazon. He also criticizes the real scope of $O$ Liberal and Diário do Pará since their number of sales, production costs, distribution by municipalities and actual investments made through 
advertising are not made public. What is known is that the rivalry between $O$ Liberal and Diário do Pará shapes the journalistic scenario of Pará state. One newspaper writes about the other, and vice versa, as their ideologies are mostly divergent.

However, talking about the plebiscite in Pará, $O$ Liberal and Diário do Pará advocated against creating the two separate states of Carajás and Tapajós out of Pará. The narrative identities created by the two newspapers conveyed memory (sameness) of a unified state and re-identity through the Pará flag yet also conveyed promise (ipseity) of separation, of break, of territorial division. O Liberal used narratives to refer to Carajás and Tapajós as unknown and needing to disconnect from each other. The Diário do Pará used narratives to refer to Carajás and Tapajós as outsiders who are trying to break Pará up into three parts. In the $A B N$ newspaper, the sense of death, of mourning, of loss is conveyed by coloring the star in the Pará flag black, its color is traditionally blue which symbolizes the union with the other Brazilian states.

$O$ Liberal had concerns over marketing patents. How much would the RMO newspaper gain or lose with the territorial division? This appeared to be the newspaper's concern in regards to the cost of the public vote. Diário do Pará was more symbolic when it came to the interests of Senator Jader Barbalho. The Brazilian politician is in favor of creating new states, especially Tapajós because he owns the Tapajós group formed by Tapajós TV which is in turn affiliated with Globo Network. He also owns Tapajós FM radio and the news portal No Tapajós currently hosted on the globo.com website (PINTO, 2015, p. 177). However, during the campaign for the plebiscite, Jader Barbalho refused to make his opinion known, hiding out behind the scenes of the plebiscite. The senator avoided exposing his views on the separatist cause so as not to damage his reputation in the polarized regions (LIMA, 2011).

Pará journalism is a hostage of two major communication groups that are closely knit with the political scene and the business world. No narrative found in O Liberal or Diário do Pará is ideologically exempt. On the contrary, the discursive characters are constructed subjectively, meaning they are previously interpreted and presented to the public according to the political criteria of the newspapers. The isolation of the Amazon in relation to other Brazilian regions does not detract from the reflections presented here. The Amazon was very close to becoming an independent country and, throughout much of Brazil's history, Pará has maintained 
direct relations with Portugal. The Pará political-communicational conjuncture is its own; however, investigations are required in order to encourage resistance to mass communication.

* This paper was translated by Vera Maria Segurado Pimentel (Universidade da Amazônia/Brazil) and revised by Lee Sharp, with the support of the Dean of Research and Postgraduate Studies of the Federal University of Pará.

NOTES

1 A preliminary version of this article was presented at the Amazonian Media Narratives WG during the 2nd Meeting of Visual Anthropology of Amazonian America (MVAAA) held in Belém (PA) from October 25 to $27,2016$.

2 Altogether, 33 major industrial and infrastructure projects were developed in order to corroborate the federal government's strategy of expanding the Amazon border through urbanization. Six of these major projects were implemented in the Amazon: Consórcio de Alumínio do Maranhão (Alumar), Ferro Carajás, Hidrelétrica de Tucuruí, Alumínio Brasileiro S.A. (Albrás), Alumina do Norte do Brasil S.A. (Alunorte) and Trombetas (BECKER, 1997, p. 65).

3 Joaquim Cardoso Magalhães Barata was a federal intervener in Pará from 1930 to 1935 . He had almost absolute power in the state. Journalist Paulo Maranhão, owner of the Folha do Norte newspaper, was directly opposed to the orders and violations committed by Magalhães Barata. Maranhão was attacked and his adversary arranged for him to be pelted with feces. Cf.: http://novoblogdobarata.blogspot.com.br/2012/05/ historia-o-banho-de-fezes-em-paulo.html. Access: Aug.20, 2016.

4 After leaving the state government of Pará in 1986, Jader Barbalho became minister of Agricultural Reform and Social Security for the government of José Sarney (1985-89). He returned to the state government of Pará between 1990 and 1994. He assumed the position of senator of the Republic in 1994, but resigned in 2001 after accusations made by Senator Antônio Carlos Magalhães about diverting public funds from the Amazon Superintendency (Sudam), the Pará State Bank and the National Institute of Colonization and Agricultural Reform. He was elected federal congressman in 2002 and 2006. He 
returned to the Senate in 2010. (VELOSO, 2008, 83). Cf .: http://www. jaderbarbalho.com/v3/index.php/biografia/. Access: Aug. 20, 2016.

5 HEC authorized the votes in favor of and against the emergence of the new states to be registered, composed of politicians of the Legislative Assembly, the Senate and the House of Representatives who had the task of organizing and promoting the campaigns of the plebiscite. The votes registered in Pará Regional Electoral Court were: Vote against the creation of the State of the Tapajós, presided by state deputy Celso Sabino; Vote against the creation of the State of Carajás, led by federal congressman Zenaldo Coutinho; Vote for the creation of the State of Tapajós, organized by federal congresswoman Lira Maia and Procreation Vote of the State of Carajás, under the responsibility of state congressman João Salame (HIGHER ELECTORAL COURT, s.d.).

\section{REFERENCES}

BECKER, Bertha K. Amazônia. 5. ed. São Paulo: Editora Ática, 1997.

BRASIL. Título III. Da Organização do Estado. Capítulo I. Da organização político-administrativa. In: Constituição. Brasília: Senado Federal: 1988.

BRAZILIAN INSTITUTE OF GEOGRAPHY AND STATISTICS / INSTITUTO BRASILEIRO DE GEOGRAFIA E ESTATÍSTICA - IBGE. Available at: <www. ibge.gov.br> Access on: Jan.29, 2014.

BUENO, Magali Franco. O imaginário brasileiro sobre a Amazônia: uma leitura por meio do discurso dos viajantes, do Estado, dos livros didáticos de Geografia e da mídia impressa. 2002. 197f. 2002. 197p. Master thesis (Master in Geography). University of São Paulo, São Paulo, 2002.

CASTRO, Fábio Fonseca de. Macrodinâmicas da comunicação midiática na Amazônia. Boletim do Museu Paraense Emílio Goeldi. Ciências Humanas. Belém, v. 8, n. 2, p. 435-445, May-Aug. 2013. Available at: $<$ https://docs.google.com/viewer?a=v\&pid=sites\&srcid=ZGVmYXVsdG RvbWFpbnxodXBvbW5IbWF0YXxneDo3MWM3NmQyOTcwMzc1 MTVm\&p $\mathrm{li}=1>$. Access on: Feb.21, 2014.

CASTRO, Fábio Fonseca de. Os temas da identidade e da cultura no debate sobre a divisão do Pará. 2011. Avaliable at: <https://docs. google.com/viewer?a=v\&pid=sites\&srcid=ZGVmYXVsdGRvbWFpbnxodX BvbW5IbWF0YXxneDo3MWM3NmQyOTcwMzc1MTVm\&pli=1>. Acess on: Feb. 212014.

CASTRO, Fábio Fonseca de. Sistemas de comunicação na Amazônia. Revista Fronteira: estudos midiáticos. v. 14, n. 3, p. 179-191 2012. Available at: <http://revistas.unisinos.br/index.php/fronteiras/article/ 
view/fem.2012.143.01> Access on: Feb. 05, 2017.

DUTRA, Manuel. O Pará dividido: discurso e construção do Estado de Tapajós. Belém: UFPA/NAEA/PLADES, 1999.

FRANÇA, Vera Regina Veiga. Discurso de identidade, discurso de alteridade: a fala do outro. In: FRANÇA, Vera Regina Veiga. (Ed.). Imagens do Brasil: modos de ver, modos de conviver. Belo Horizonte: Autêntica, 2002, p. 27-43.

GEERTZ, Clifford. A interpretação das culturas. 1. ed. Rio de Janeiro: LTC, 2015.

GUIMARÃES, Luciano. O repertório dinâmico das cores na mídia: produção de sentido no jornalismo visual. 2006. Available at: <www. compos.org.br/data/biblioteca_504.pdf> Access on: Nov.13, 2016.

LEAL, Bruno. Saber das narrativas: narrar. In: GUIMARÃES, César; FRANÇA, Vera (Eds.). Na mídia, na rua: saberes do cotidiano. Belo Horizonte: Autêntica, 2006, p. 19-28.

LIMA, Wilson. Com medo de rejeição, personalidades do Pará se eximem de opinar. Dec. 102011 . Available at: <http://ultimosegundo. ig.com.br/brasil/pa/com-medo-de-rejeicao-personalidades-do-para-seeximem-de-opinar/n1597404585227.html> Access on: April 14, 2013.

MARTINO, Luís Mauro Sá. Comunicação e identidade: quem você pensa que é? São Paulo: Paulus, 2010.

MARTINO, Luís Mauro Sá. De um eu ao outro: narrativa, identidade e a comunicação com a alteridade. Revista Parágrafo, v. 4, n. 1, 2016. Available at: <http://revistaseletronicas.fiamfaam.br/index.php/recicofi/ article/view/377/376> Access on: Jan. 29, 2017.

MASSARANI, Luisa Medeiros; SEIXAS, Netília Silva dos Anjos; CARVALHO, Vanessa Brasil de. La ciencia en O Liberal: estudio de uno de los principales diarios de la Amazonía brasileña. Chasqui. n. 122. Jun. 2013. Available at: <www.revistachasqui.org/index.php/chasqui/article/view/74/86> Access on: Aug. 20, 2016.

MENDONÇA, Ricardo Fabrino; CAL, Danila. Quem pode falar no Facebook? O "autocontrole" em um grupo sobre o plebiscito acerca da divisão do Pará. Revista Debates, v. 6, n. 3, 2012. Available at: <http://seer.ufrgs. br/debates/article/view/30928> Access on: Set. 13, 2015.

MOTTA, Luiz Gonzaga. Análise pragmática da narrativa jornalística. In: LAGO, Cláudia; BENETTI, Marcia (Eds.). Metodologia de pesquisa em jornalismo. Petrópolis (RJ): Vozes, 2007, p. 143-167.

PAES LOUREIRO, João de Jesus. Cultura amazônica: uma poética do imaginário. Belém: Cejup, 1995. 
PINTO, Lúcio Flávio. A mesma origem dos jornais rivais. Observatório da Imprensa, 448, de Aug. 28, 2007. Available at: <www. observatoriodaimprensa.com.br/news/view/a_mesma_origem_dos_ jornais_rivais> Access on: Jul. 19, 2015.

PINTO, Lúcio Flávio. Os jornais fraudados. Observatório da Imprensa, 760, de Aug. 20, 2013. Available at: <http://observatoriodaimprensa. com.br/imprensa-em-questao/_ed760_os_jornais_fraudados> Access on: 29 jan. 2017.

PINTO, Lúcio Flávio. O Pará dos paraenses (proposta de um programa político sério). Edição do autor. 1994.

PINTO, Pâmela Araújo. Mídia regional brasileira: características dos subsistemas midiáticos das regiões Norte e Sul. 2015. 337f. Doctorate Dissertation (Doctorate in Communication). Fluminense Federal University, Niterói (RJ), 2015.

RICOEUR, Paul. O conflito das interpretações: ensaios de hermenêutica. Rio de Janeiro: Imago Editora, 1978.

RICOEUR, Paul. O percurso do reconhecimento. Edições Loyola: São Paulo, 2006.

RICOEUR, Paul. O si-mesmo como outro. WMF Martins Fontes: São Paulo, 2014.

RICOEUR, Paul. Tempo e narrativa: a intriga e a narrativa histórica. WMF Martins Fontes: São Paulo, 2010.

SCHMINK, Marianne; WOOD, Charles H. Conflitos sociais e a formação da Amazônia. Belém: Ed. UFPA, 2012.

SEIXAS, Netília Silva dos Anjos; CASTRO, Avelina Oliveira de. Imprensa e poder na Amazônia: a guerra discursiva do paraense $O$ Liberal com seus adversários. Revista Comunicação Midiática. v. 9. n. 1. Jan./Apr. 2014. Available at: <www2.faac.unesp.br/comunicacaomidiatica/index.php/ comunicacaomidiatica/article/view/465/254> Access on: Aug. 20, 2016.

STATES AND CAPITAL OF BRAZIL. Pará flag. Available at: <http://www. estadosecapitaisdobrasil.com/bandeira/bandeira-do-para/> Access on: Feb.10, 2016.

THOMPSON, John B. Ideologia e cultura moderna: teoria social crítica na era dos meios de comunicação de massa. 9. ed. Petrópolis (RJ): Vozes, 2011.

TRIBUNAL SUPERIOR ELEITORAL. Available at: <www.tse.jus.br/ eleicoes/plebiscitos-e-referendos> Access on: 23 mar. 2013.

VAN DIJK, Teun Adrianus. Cognição, discurso e interação. 3. ed. São Paulo: Contexto, 2000. 
VAN DIJK, Teun Adrianus. Discurso e poder. 2. ed. São Paulo: Contexto, 2015.

VAN DIJK, Teun Adrianus. Ideology: A Multidisciplinary Approach. Londres: SAGE, 1998.

VELOSO, Maria do Socorro Furtado. Imprensa, poder e contrahegemonia na Amazônia: 20 anos do Jornal Pessoal (1987-2007). 2008. 317 f. Doctorate Dissertation (Doctorate in Communication). University of São Paulo, São Paulo, 2008.

Alda Cristina Costa. Professor of the Postgraduate Program in Communication, Culture and the Amazon at the Federal University of Pará. Phd student of Communication, Languages and Culture at the University of Amazônia (current). Coordinator of projects and research groups "Media and Violence: perceptions and representations in the Amazon" and "Contemporary Narratives in the Pará Amazon".

Thaís Luciana Corrêa Braga. Master's in Communication Sciences from the Federal University of Pará, journalist in the Federal University of Pará technical-administrative staff. Member of projects and research groups "Media and Violence: perceptions and representations in the Amazon" and "Contemporary Narratives in the Pará Amazon".

Evelyn Cristina Ferreira de Aquino. Master's in Communication Sciences from the Federal University of Pará, specializes in Journalism, Citizenship and Public Policy, an Advertising and Propaganda graduate from the University of Amazonia. Member of the project and research group "Contemporary Narratives in the Pará Amazon". 